\title{
Strengthening National Character Education through Physical Education: An Action Research in Indonesia
}

\author{
Ayi Suherman* \\ Universitas Pendidikan Indonesia \\ Bandung, Indonesia \\ Tedi Supriyadi \\ Universitas Pendidikan Indonesia \\ Bandung, Indonesia \\ Sulthan Hadist Ismaiedh Cukarso \\ Universitas Pendidikan Indonesia \\ Bandung, Indonesia
}

\begin{abstract}
Since the enactment of the 2013 Curriculum in Indonesia, teachers are required to be able to integrate character education in physical education (PE) as a subject presented in the 2013 Curriculum. In the implementation, PE teachers have not entirely meet the demands of the 2013 Curriculum in terms material development, method, and evaluation that have not yet explored students' character. Therefore, this research aims at improving PE teacher physical education teachers' understanding and skills in developing national characters such as religious, nationalist, independent, mutual cooperation, and integrity. The action research report presented in this article exemplifies the results of the work of collaborative teams involved in making critical reflective steps in developing students' character through physical learning that has so far tended to have no value. The action implementation showed an improvement in the pedagogical competence of the teachers in developing five national characters through PE.
\end{abstract}

Keywords: 2013 Curriculum; Character Education; Physical Education.

\section{Introduction}

The inculcation of character values in each subject is one of the characteristics and demands of the 2013 Curriculum (Qoriah, 2013). The 2013 Curriculum is the

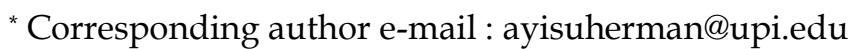


applied curriculum in Indonesia today. Physical Education (PE) is one of the subjects presented in the 2013 Curriculum with the nomenclature of physical education in sports and health (hereinafter referred to as Physical Education/PE). This means that PE bears the same responsibilities as other subjects in developing student character in the learning process. Therefore, PE is not a supplementary subject but a national asset that is expected to function optimally to develop the nation and the character of Indonesian people. Thus it is necessary that every PE teacher is able to develop students' character in the learning process.

The expressions "sports build character" and "mens sana in corpore sano" in the world of sports or within the framework of PE seem to need reconstruction because many writings on character in PE are only claims only without empirical scientific evidence (Maksum, 2017). Only little research on character in PE can be found to have solid scientific evidence that PE is able to build character (Maksum, 2017; Bailey, 2006; Docheff, 1997; Koç \& Esentürk, 2018). This can mean that the optimization of character development through PE has not yet been realized because the learning process is still considered to be meaningless (Maksum, 2005). In addition, PE teachers still apply old paradigms of identical Physical Learning by learning one of the sports or paradigms that tends to emphasize on head start rather than heart start (Ratna, 2009; Suherman, 2018). Cases such as antisocial personality disorder, learning disability, and so on are born from the headstart education paradigm (Ratna, 2009, p. 37). It also shows that success in PE learning is closely related to the quality of the teachers (Maksum, 2010).

Therefore, this research is intended to improve PE teachers' understanding and skills in developing students' character through PE learning, in which PE teachers perform the function as an educator and they are not only transferring knowledge but also transferring values to grow the national character values in students in preparing for the golden generation of 2045 who is devoted, nationalist, durable, independent, and has global competitive advantages (J.Julia and Tedi Supriyadi, 2017). Additionally, this research was conducted as an effort to contribute to PE in realizing the goals of national education. The goals are to educate the nation and develop Indonesian people as a whole, which means people who have faith and devotion to God Almighty, virtuous character, knowledge and skills, physical and spiritual health, a steady and independent personality, and a sense of community and national responsibility (UU No 20 Tahun, 2003). At the same time, this research appreciates the Presidential Regulation No. 87 of 2017 concerning Strengthening Character Education, which is followed up with Decree of the Minister of Education and Culture of the Republic of Indonesia Number 20 of 2018 concerning Strengthening of Character Education in formal education units by developing five core characters namely religious, nationalist, independent, mutual cooperation, and integrity as national values which needs to be developed in students at school.

The issue of character education in relation to PE has long been a discourse in the world of education. There are several research related to character problems in PE, for example in the 1930s by McCloy (1930) entitled Character Building through Physical Education, Jay B Nash (1933) who wrote The Role of Physical 
Education in Character Education, Frank L Oktavec's (1934) entitled Physical Education as a Character Builder. From the 60s there is Maraj's (1965) entitled Physical Education and Character. In the 1980s there is Romance's (1988) entitled Promoting Character Development in Physical Education. In the 1990s, there are Docheff's (1997) entitled Character in Sport and Physical Education, Gough's (1998) entitled A Practical Strategy for Emphasizing Character Development in Sports and Physical Education. In the 2000s, there are Crum's (2006) entitled Character Development through Sport Empirical Evidence or Wishful Thinking? And Arifin \& Warni's (2017) entitled Character Building Values in Sports Development. These studies stated that PE is an asset that can be used in growing character in students or sports people but practically has not touched on character development through education from a pedagogical point of view. Thus, this research seeks to address the problem of the strategic steps in developing the national character of students in elementary schools through PE learning. The proposed research question is: What are the strategic steps to develop teachers' pedagogy understanding and skills in developing elementary school students' national character through PE learning?

\section{Theoretical Framework}

To form a noble character in students is not simple yet not impossible. Building character requires patience, perseverance, long time, appropriate methods, techniques or strategies, and an environment that supports it. Therefore, character development cannot be learned without reference to the social interactions that we experience even early in life (Maraj, 1965). Likewise, character building cannot be conducted by one or two subjects partially but must be by all subjects comprehensively.

Sukadiyanto (2008 p.3) stated that PE has two meanings namely education through physical activities. Education through physical activities means that the physical activities in PE are used as tools or media to educate, while the purpose of education is the same as education in general namely cognitive, affective, psychomotor, and kinesthetic aspects. PE uses physical activities as tools to educate (Rahayu, 2013) Therefore, education is not only a transfer of knowledge but also a transfer of value (J.Julia and Supriyadi, 2017; Supriyadi, 2016). This can mean that PE not only deals with physical matters but also mental, emotional, and social aspects (Wuest, Deborah A and Bucher, 2003).

In the standard content of PE learning, according to BSNP (2004 p.513), the goals of PE include "... (4) laying the foundation of a strong moral character through internalization of the values contained in Physical Education in Sport and Health, (5) develop sportsmanship, honesty, discipline, responsibility, cooperation, confidence, and democracy, ...". That is why the government through the Ministry of National Education rolled out a program to strengthen character education in schools that develop five core characters namely religious, mutual cooperation, nationalist, integrity, and independence. This shows that the character is the axis of Education (Dalyono \& Lestariningsih, 2016). Therefore, these five character domains (religious, mutual cooperation, nationalist, integrity, and independence) become the foundation developed in PE learning in this research. 
The effort to strengthening character education at schools in Indonesia, which focuses on the abovementioned five domains of characters, emphasizes on: 1) The preventive actions to respond to negative influences of information and communication technology and teenager lifestyle that neglects the religious and local wisdom values; 2) Crisis of identity and life goals disorientation as impact of lack of parental assistance; and 3) Inoptimal students' potential development in harmonizing their heart (ethics), thought (literacy), feeling (aesthetics), and body (kinesthetic) (Kemendikbud, 2017).

In addition, the implementation of the education process in Indonesia must be in line with the functions and objectives mandated by the Law No. 20 of 2003 that national education functions to develop capabilities and shape the dignified character and civilization of the nation in the context of developing the life of the nation, aiming to the development of the potential of students to become human beings who believe and fear God Almighty, noble, healthy, knowledgeable, capable, creative, independent and become citizens of a democratic and responsible" (Indonesia, 2003).

Therefore, the five character domains are the embodiment of the mandate of the law so that they can be referred to as national characters because these five core characters are the spirit in the implementation process of the national education system. In meaning that the national education is based on Pancasila and 1945 Constitution of the Republic of Indonesia, rooted in religious values, Indonesian national culture and is responsive to the demands of changing times (Indonesia, 2003).

There are six important points that need to exist in an effort to develop character. According to Jay B Nash (1933), the points are 1) education must be a doing phenomenon, 2) the child must be interested in the act, 3) participation in activities must be satisfying, 4) the activities should offer opportunities for integration, 5) the activities must provide opportunity for leadership and followership, and 6) the activities must offer opportunity for self-direction.

There are several stages of character development. Firstly, students face a moral dilemma, then they communicate it to related parties, and then they make a behavioral decision. If the final decision regards everyone's rights and responsibilities, then they have gained high the level of character.

One example of development in character is when a PE student who jokes about awkward classmates. His clever, though hurtful jokes made some classmates laugh. In making fun of the awkward classmates, he has reasoned and behaved in a self-centered way. As he receives negative feedback from the ridiculed and other students, he could become more aware of the negative effects his actions and starts to behave in a kinder and less self-centered way. This change in behavior shows character development.

\section{Methods}

This section presents the related methodology used in an effort to achieve the results of this research including the research design, the collaborative aspects, the steps of the research, the research subjects, and the location of the research. 


\subsection{Research Design}

This research used action research design. Action research is a popular design that is widely used in pedagogical research (Edwards-Groves \& Kemmis, 2016; Jefferson, 2014; Niemi, 2018; Supriyadi \& Julia, 2019; Zuber-Skerritt, 2015). In addition to this reasons, action research provides the opportunity for researchers to find new efforts to make changes that are in accordance with conditions and needs (Darwis, 2016). The most distinctive aspect of this design is that improvements can be made by the problem solver (Bozkus \& Bayrak, 2019; Greenwood \& Levin, 2006). Action research design is practically a design that seeks to explore problems to find solutions (Creswell, 2002). This is in line with the problem of PE teachers in developing national character in students that requires intensive solutions in the learning process, considering that developing student character is a curriculum requirement that applies in Indonesia as well as government programs on strengthening character education that must be implemented in every learning activity in schools. Moreover, the action research design in this research is an attempt to understand self-practice so as to enable improvements in every action taken (Kemmis \& McTaggart, 2005; Kemmis, McTaggart, \& Nixon, 2013; McTaggart, 1994) Through action research, the planning, implementation, and reflection on every step could take place (McTaggart, 1996).

\subsection{Collaborative Aspects}

Collaboration is an important aspect of action research (Bruce, Flynn, \& StaggPeterson, 2011; Creswell, 2002; Ferguson-Patrick, 2007; Jaipal \& Figg, 2011; Leeman, van Koeven, \& Schaafsma, 2018; Somekh, 2010). In conducting research, the researchers use the principles of collaboration as a characteristic of action research design (Creswell, 2002). Collaboration in this research involved researchers as lecturers of PE course, peers who were equally capable of $\mathrm{PE}$, and school principals and PE teachers at one of the elementary schools in Sumedang Regency. Researchers also collaborated with one of the lecturers who had expertise in the field of Islamic education because in a series of actions, especially in the practice of physical education, there was an inculcation of religious character values. In addition, researchers also collaborated with one of the student activity units in the field of sports which was involved in a series of action. Research that employ collaborative action research processes in education involve collaboration between teachers, or between teachers and researchers (Messiou, 2019; Zech, Gause-Vega, Bray, Secules, \& Goldman, 2000).

\subsection{Research Procedure}

Broadly, this research was divided into three major types of activities, namely 1 ) Pre-action analysis and evaluation activities, 2) Action and critical evaluation of PE learning, and 3) Post-action evaluation in PE learning. Each activity had several stages.

The pre-action activities had several stages, namely 1) a survey related to the insights and perceptions of teachers about character education in PE learning, 2) observation on learning planning documents and PE learning practices, 3) analyzing the results of pre-action evaluations related to learning outcomes carried out by the teacher before conducting the action. This pre-action activity was intended to take a view of the practices and results of learning in the 
elementary school as they are. The results of the analysis were used as a reference in determining the steps of action as an effort for improvement.

In action activities and critical evaluation of PE learning, there were two stages namely 1) implementation of actions in accordance with planning, and 2) reflection on every action taken. In this research, these stages produced eight critical-reflective steps in an effort to improve the PE teachers' pedagogical competencies in developing student character.

The post-action evaluation activities included the final test to identify changes in the PE teachers in their understanding of and the skills in developing character, and this stage was intended to view the results of post-action learning related to the characters that appear on students.

\subsection{Research Subjects and Location}

The subjects in this research were elementary school PE teachers in Sumedang Regency. The sample consisted of 28 teachers ( 20 males and 8 females) spread across four areas in Sumedang Regency. Each area was represented by seven elementary schools, and each elementary school was represented by one PE teacher.

This sampling technique was purposive sampling in which the researcher determined the sample with certain considerations and criteria in accordance with the objectives of the research. The consideration was that each PE teacher was required to be able to integrate character education in each subject in an effort to develop national character in elementary school students. The sample criteria were PE teachers who taught in elementary schools.

\subsection{Data Collection}

In this research, data were collected in several ways namely survey, observation, focus group discussion (FGD), and semi-structured interviews. The survey was conducted through Google Docs using a Likert scale and Gutman scale. Google Docs has become a profitable and easy-to-use survey tool (Allen \& Seaman, 2007; Brigham, 2014; Chiu, Cheng, \& Wu, 2016; Lin, Chang, Hou, \& Wu, 2016; Travis, 2010; Widhiarso, 2011). Therefore, the research instrument consisted of observation guidelines, interview guidelines, and questionnaires. 
As for the guidelines for observation in this research, there were several rubrics as in the following tables:

Table 1. Lesson Plan Document Evaluation Rubric

\begin{tabular}{|c|c|c|c|c|c|c|c|c|}
\hline \multirow{2}{*}{$\mathrm{NO}$} & \multirow{2}{*}{ ACTIVITY } & \multirow{2}{*}{ INDICATOR } & \multicolumn{5}{|c|}{ QUALIFICATION } & \multirow{2}{*}{$\begin{array}{l}\mathrm{SCO} \\
\mathrm{RE}\end{array}$} \\
\hline & & & 5 & 4 & 3 & 2 & 1 & \\
\hline \multirow[t]{2}{*}{1} & \multirow[t]{2}{*}{$\begin{array}{l}\text { Learning } \\
\text { Objectives }\end{array}$} & $\begin{array}{l}\text { a. They are aligned } \\
\text { with curricular } \\
\text { Competence } \\
\text { Standard and } \\
\text { achievement } \\
\text { indicator }\end{array}$ & & & & & & \\
\hline & & $\begin{array}{l}\text { b. The objectives are } \\
\text { formulated } \\
\text { comprehensively } \\
\text { and clearly }\end{array}$ & & & & & & \\
\hline \multirow[t]{3}{*}{2.} & \multirow[t]{3}{*}{$\begin{array}{l}\text { Learning } \\
\text { Materials }\end{array}$} & $\begin{array}{l}\text { a. They are based on } \\
\text { the main learning } \\
\text { material in the } \\
\text { syllabus }\end{array}$ & & & & & & \\
\hline & & $\begin{array}{l}\text { b. The learning } \\
\text { materials selected } \\
\text { are appropriate for } \\
\text { students' } \\
\text { characteristics }\end{array}$ & & & & & & \\
\hline & & $\begin{array}{ll}\text { c. The learning } \\
\text { materials selected } \\
\text { are appropriate for } \\
\text { students' thinking } \\
\text { skill level }\end{array}$ & & & & & & \\
\hline \multirow[t]{2}{*}{3} & \multirow[t]{2}{*}{$\begin{array}{l}\text { Learning } \\
\text { Methods }\end{array}$} & $\begin{array}{l}\text { a. The learning } \\
\text { method selected are } \\
\text { relevant to the } \\
\text { learning objectives } \\
\text { and materials } \\
\end{array}$ & & & & & & \\
\hline & & $\begin{array}{ll}\text { b. The learning } \\
\text { methods are varied }\end{array}$ & & & & & & \\
\hline \multirow[t]{7}{*}{4.} & $\begin{array}{l}\text { Learning } \\
\text { Stages }\end{array}$ & & & & & & & \\
\hline & \multirow{3}{*}{$\begin{array}{l}\text { 1.1. Opening } \\
\text { Activity }\end{array}$} & $\begin{array}{ll}\text { a. } & \begin{array}{l}\text { Orientation on } \\
\text { learning activities }\end{array} \\
\end{array}$ & & & & & & \\
\hline & & $\begin{array}{l}\text { b. Apperception/guid } \\
\text { e pretest }\end{array}$ & & & & & & \\
\hline & & $\begin{array}{l}\text { c. Determining ways } \\
\text { to motivate the } \\
\text { students }\end{array}$ & & & & & & \\
\hline & \multirow{3}{*}{$\begin{array}{l}\text { 1.2. } \text { Main } \\
\text { Activity }\end{array}$} & $\begin{array}{ll}\text { a. } & \begin{array}{l}\text { Determining types } \\
\text { of activities }\end{array} \\
\end{array}$ & & & & & & \\
\hline & & $\begin{array}{ll}\text { b. Arranging learning } \\
\text { steps }\end{array}$ & & & & & & \\
\hline & & $\begin{array}{ll}\text { c. } & \text { Determining } \\
\text { allotted learning } \\
\text { time }\end{array}$ & & & & & & \\
\hline
\end{tabular}




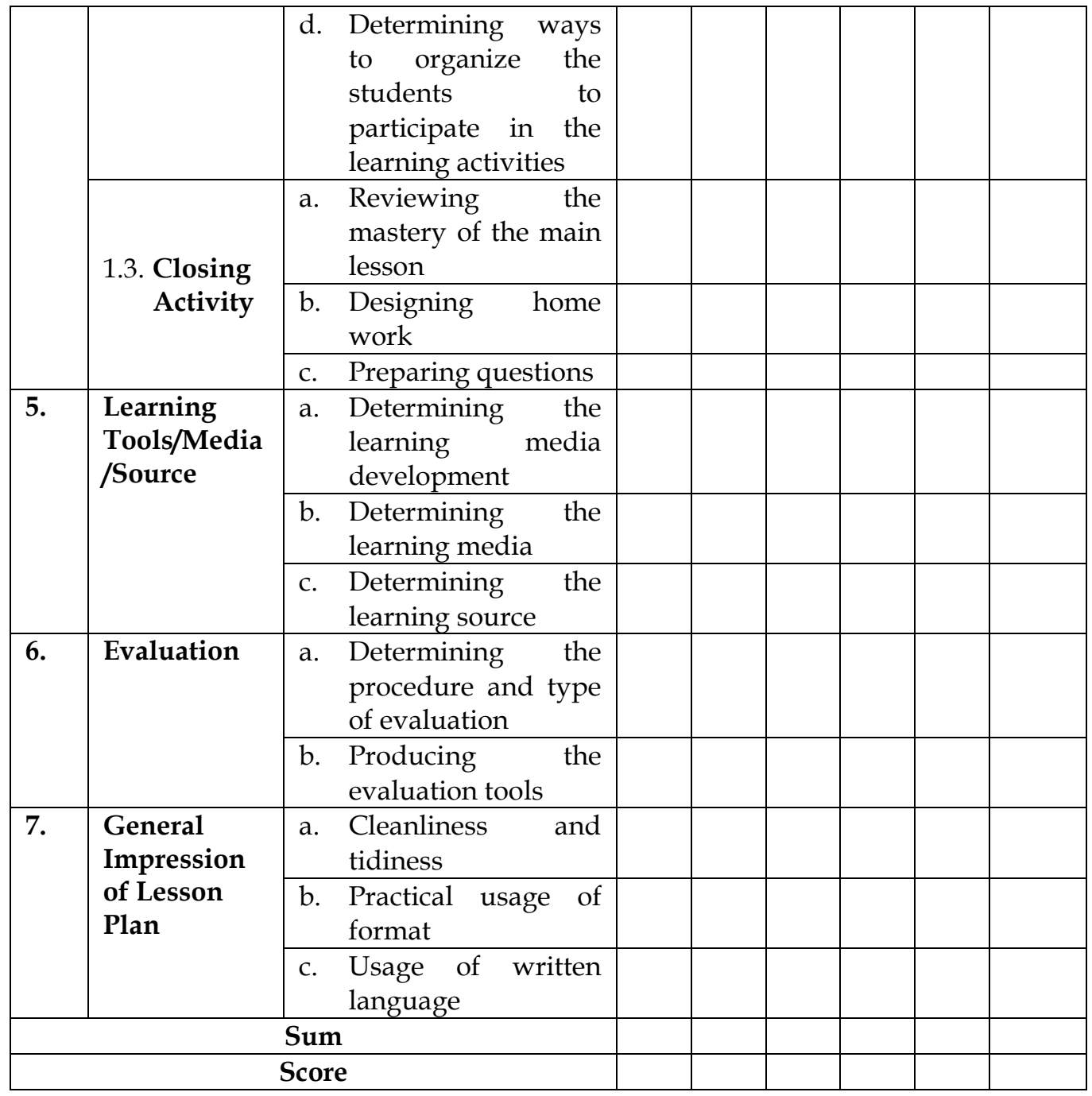

Information

Score $=\underline{\text { Sum of Gained Score }}$ Maximum Score

Criteria:

Very Good $=91-100$,

Good $\quad=76-90$

Fair $\quad=61-75$

Poor $=51-60$

Very poor $\quad=<50$ 
Table 2. PE Teacher's Learning Practice Evolution Rubric

\begin{tabular}{|c|c|c|c|c|c|c|c|c|}
\hline \multirow{2}{*}{$\mathrm{NO}$} & \multirow{2}{*}{ ACTIVITY } & & \multicolumn{5}{|c|}{ QUALIFICATION } & \multirow{2}{*}{ SCORE } \\
\hline & & & 5 & 4 & 3 & 2 & 1 & \\
\hline \multirow[t]{3}{*}{1.} & \multirow[t]{3}{*}{$\begin{array}{l}\text { OPENING } \\
\text { ACTIVITY }\end{array}$} & $\begin{array}{l}\text { a. Delivering the routine } \\
\text { class task }\end{array}$ & & & & & & \\
\hline & & $\begin{array}{l}\text { b. Delivering the linking } \\
\text { material/apperception }\end{array}$ & & & & & & \\
\hline & & $\begin{array}{l}\text { c. Motivating the students to } \\
\text { participate in the learning } \\
\text { activities }\end{array}$ & & & & & & \\
\hline \multirow[t]{14}{*}{2} & \multirow{14}{*}{$\begin{array}{l}\text { MAIN } \\
\text { ACTIVITY }\end{array}$} & a. Delivering the materials & & & & & & \\
\hline & & $\begin{array}{l}\text { b. Using varied learning } \\
\text { methods, appropriate to } \\
\text { the basic competencies, } \\
\text { students' skills, situations, } \\
\text { and conditions }\end{array}$ & & & & & & \\
\hline & & c. Using leaning tools/media & & & & & & \\
\hline & & $\begin{array}{l}\text { d. Implementing the learning } \\
\text { activities in a logical order }\end{array}$ & & & & & & \\
\hline & & $\begin{array}{ll}\text { e. } & \text { Using the learning time } \\
\text { efficiently and effectively }\end{array}$ & & & & & & \\
\hline & & $\begin{array}{ll}\text { f. } & \begin{array}{l}\text { Mastering the learning } \\
\text { material }\end{array}\end{array}$ & & & & & & \\
\hline & & g. Organizing the students & & & & & & \\
\hline & & $\begin{array}{l}\text { h. Providing opportunities } \\
\text { for the students to } \\
\text { participate actively }\end{array}$ & & & & & & \\
\hline & & $\begin{array}{l}\text { i. Interaction between the } \\
\text { teacher and students, } \\
\text { among the students }\end{array}$ & & & & & & \\
\hline & & $\begin{array}{l}\text { j. } \begin{array}{l}\text { Showing openness to the } \\
\text { students' opinion }\end{array} \\
\end{array}$ & & & & & & \\
\hline & & $\begin{array}{ll}\text { k. } & \begin{array}{l}\text { Developing a healthy and } \\
\text { harmonious personal } \\
\text { relationship }\end{array} \\
\end{array}$ & & & & & & \\
\hline & & $\begin{array}{l}\text { 1. } \begin{array}{l}\text { Using appropriate, correct, } \\
\text { and effective language }\end{array} \\
\end{array}$ & & & & & & \\
\hline & & $\begin{array}{l}\mathrm{m} . \\
\text { Implementing evaluation } \\
\text { along the process }\end{array}$ & & & & & & \\
\hline & & $\begin{array}{l}\text { n. Implementing evaluation } \\
\text { at the end of the learning }\end{array}$ & & & & & & \\
\hline \multirow[t]{2}{*}{3.} & \multirow[t]{2}{*}{$\begin{array}{l}\text { CLOSING } \\
\text { ACTIVITY }\end{array}$} & $\begin{array}{l}\text { a. Delivering the learning } \\
\text { summary }\end{array}$ & & & & & & \\
\hline & & b. Implementing follow-up & & & & & & \\
\hline & & Sum & & & & & & \\
\hline & & Score & & & & & & \\
\hline
\end{tabular}

\section{Information}

Score $=\underline{\text { Sum of Gained Score }}$

\section{Maximum Score}


Criteria:

$\begin{array}{lll}\text { Very Good } & =91-100, \\ \text { Good } & =76-90 \\ \text { Fair } & =61-75 \\ \text { Poor } & =51-60 \\ \text { Very poor } & =<50\end{array}$

Table 3. Evaluation Rubric of Student Character Development in PE Learning

\begin{tabular}{|c|c|c|c|c|}
\hline No & $\begin{array}{l}\text { Main } \\
\text { Character }\end{array}$ & Indicator & $\begin{array}{l}\text { Shown } \\
\text { (1) }\end{array}$ & $\begin{array}{l}\text { Not } \\
\text { shown } \\
(0)\end{array}$ \\
\hline \multirow[t]{7}{*}{1} & \multirow[t]{7}{*}{ Religious } & $\begin{array}{l}\text { a. The students begin the learning by } \\
\text { praying and lead by the class } \\
\text { leader. }\end{array}$ & & \\
\hline & & $\begin{array}{l}\text { b. The class leader allows his/her } \\
\text { classmates to pray according to } \\
\text { their belief. }\end{array}$ & & \\
\hline & & $\begin{array}{l}\text { c. The students follow the student } \\
\text { leader's instruction in praying. }\end{array}$ & & \\
\hline & & $\begin{array}{l}\text { d. The students pray in an orderly } \\
\text { manner. }\end{array}$ & & \\
\hline & & $\begin{array}{l}\text { e. The students are dressed neatly and } \\
\text { clean. }\end{array}$ & & \\
\hline & & $\begin{array}{l}\text { f. The class leader checks the } \\
\text { cleanliness and neatness of his/her } \\
\text { classmates' uniform and } \\
\text { fingernails. }\end{array}$ & & \\
\hline & & $\begin{array}{l}\text { g. The class leader leads and asks to } \\
\text { clean the learning location. }\end{array}$ & & \\
\hline \multirow[t]{3}{*}{2} & \multirow[t]{3}{*}{ Nationalist } & $\begin{array}{l}\text { a. Good effort to understand the given } \\
\text { examples of sport/martial art/self- } \\
\text { defense movements }\end{array}$ & & \\
\hline & & b. Assisting teammates to play well & & \\
\hline & & $\begin{array}{l}\text { c. The students follow the learning in } \\
\text { a cheerful atmosphere }\end{array}$ & & \\
\hline \multirow[t]{4}{*}{3} & \multirow[t]{4}{*}{ Independent } & $\begin{array}{l}\text { a. The students follow physical } \\
\text { activities according to their } \\
\text { maximum capacity }\end{array}$ & & \\
\hline & & $\begin{array}{l}\text { b. The students arrive at the field on } \\
\text { time }\end{array}$ & & \\
\hline & & $\begin{array}{l}\text { c. The students follow the teacher's } \\
\text { command and respect the rules of } \\
\text { the game and their tradition }\end{array}$ & & \\
\hline & & $\begin{array}{l}\text { d. Have courage to deliver opinion in } \\
\text { the learning activity }\end{array}$ & & \\
\hline
\end{tabular}




\begin{tabular}{|c|c|c|c|}
\hline & & $\begin{array}{l}\text { e. Critical in understanding an } \\
\text { instruction in the learning activity }\end{array}$ & \\
\hline \multirow[t]{3}{*}{4} & \multirow{3}{*}{$\begin{array}{l}\text { Mutual } \\
\text { Cooperation }\end{array}$} & a. Able to cooperate with teammates & \\
\hline & & $\begin{array}{l}\text { b. Have courage to lead a team in a } \\
\text { group game }\end{array}$ & \\
\hline & & c. Supporting the teammates & \\
\hline \multirow[t]{5}{*}{5} & \multirow[t]{3}{*}{ Integrity } & $\begin{array}{l}\text { a. Admitting mistakes made be } \\
\text { him/herself }\end{array}$ & \\
\hline & & b. Respecting victory or loss & \\
\hline & & $\begin{array}{l}\text { c. Respecting the opponents and } \\
\text { officials }\end{array}$ & \\
\hline & Sum & & \\
\hline & Score & & \\
\hline
\end{tabular}

Criteria

Score $=$ Gained Score $\times 100 \%$
$\begin{array}{ll}\text { Maximum Score } \\ \text { Very Good } & =81 \%-100 \%, \\ \text { Good } & =61 \%-80 \% \\ \text { Fair } & =41 \%-60 \% \\ \text { Poor } & =21 \%-40 \% \\ \text { Very Poor } & =0 \%-20 \%\end{array}$

\subsection{Data Analysis Technique}

Data analysis was performed using qualitative and quantitative techniques. The qualitative data analysis was performed on data obtained from interviews, observations, and FGDs. The interviews were recorded, transcribed, and categorized based on the activities conducted. The data obtained from observation and FGDs were coded and categorized to see the recurrent patterns. Meanwhile, the quantitative data analysis was performed on observational and questionnaire data. These numerical data were categorized into a percentage range and associated with the criteria developed. Finally, the data obtained from those instruments were combined based on the categorization and percentage ranges to be analyzed based on the recurring patterns, hence resulting in valid conclusion.

\section{Results}

\subsection{Pre-Action Analysis}

This activity was carried out in two stages. The first stage was a survey of teachers about character-based PE learning and the second was an observation of student behavior at four elementary schools in the Sumedang Regency.

A total of $28 \mathrm{PE}$ teachers who were the research subjects were given survey instruments using the Guttman scale. This survey was given to find out their 
experiences and perceptions about the way they teach PE, their learning outcomes, and their desires related to their ability in teaching PE. The survey results are presented in Table 4.

Table 4. Insight on Character Education

\begin{tabular}{|c|c|c|}
\hline Insight & Yes & No \\
\hline $\begin{array}{l}\text { Have you ever heard of character education or strengthening of } \\
\text { character education? }\end{array}$ & 28 & 0 \\
\hline Have you ever learned about the concept of character education? & 28 & 0 \\
\hline $\begin{array}{l}\text { Have you ever attended training on character education in a } \\
\text { workshop or seminar? }\end{array}$ & 28 & 0 \\
\hline Have you implemented character education in your field of study? & 28 & 0 \\
\hline $\begin{array}{l}\text { Is the learning process you carried out has developed students' } \\
\text { characters? }\end{array}$ & 21 & 7 \\
\hline
\end{tabular}

Table above shows that the concept of character education for the PE teachers was not something new. Character education is a term that they had already known. Based on their acknowledgment, 28 (100\%) teachers had known the term and learned the concept of character education. $28(100 \%)$ teachers stated that they obtained the materials on character education from workshops or seminars. All of the teachers who were the research subjects claimed to have implemented it and $21(75 \%)$ claimed to have succeeded in developing the students' character. It can be concluded that the subjects already had knowledge of the concept of character education and most of them claimed to have succeeded in implementing character education in the learning process. Next is exploring the teachers' motivation in instilling character in their field of study namely Physical Education. The survey was conducted using a Likert scale (Allen \& Seaman, 2007). The survey results can be seen in Table 5 as follows:

Table 5. Motivation of Internalizing Character Value

\begin{tabular}{|c|c|c|c|c|c|}
\hline Motivation & $\begin{array}{l}\text { Strongly } \\
\text { Disagree }\end{array}$ & Disagree & $\begin{array}{l}\text { Rather } \\
\text { Disagree }\end{array}$ & Agree & $\begin{array}{l}\text { Strongly } \\
\text { Agree }\end{array}$ \\
\hline $\begin{array}{l}\text { It is important for all PE teachers } \\
\text { to master the concept of character } \\
\text { education. }\end{array}$ & & & & 4 & 24 \\
\hline $\begin{array}{l}\text { Every learning process in PE } \\
\text { must include character values. }\end{array}$ & & & & 26 & 2 \\
\hline $\begin{array}{l}\text { All main characters in the } \\
\text { character education strengthening } \\
\text { must be applied in PE learning }\end{array}$ & & & & 25 & 3 \\
\hline
\end{tabular}

Based on Table 5 above, it can be seen the subjects' perceived that it was all important for all $\mathrm{PE}$ teachers to master the concept of character education. This is evident in Table 5 above as four (14.28\%) subjects agreed, and $24(85.71 \%)$ subjects strongly agreed. In addition, 26 (92.85\%) subjects agreed and two 
$(7.14 \%)$ strongly agreed that PE learning must contain character values and they also stated that all main characters in strengthening character education promoted by the government must be applied in PE learning. It can be inferred that all subjects had a commitment in developing character and applying core characters in PE learning as a reinforcement of character education. It can also be interpreted that the research subjects had a strong commitment to develop character values in PE learning.

To obtain more information on the subjects' commitment, the lesson plan documents that they had made were observed. In observing these documents, the researchers collaborated with the principal in providing an evaluation of the documents.

By using the instruments as in Table 1, the results of the assessment on lesson plan documents from each school principal is presented in Table 6 as follows:

Table 6. Evaluation Results by the Principals on the PE Teachers' Lesson Plan Documents

\begin{tabular}{lc}
\hline Evaluation & Number of Subject \\
\hline Very Good & 4 \\
Good & 24 \\
Fair & 0 \\
Poor & 0 \\
Very Poor & 0 \\
\hline Sum & $\mathbf{2 8}$ \\
\hline
\end{tabular}

Based on the table above, it can be seen that the results of the principals' evaluation on the lesson plan documents made by the PE teachers is good for 24 $(85.71 \%)$ subjects and very good for four $(14.28 \%)$ subjects. Furthermore, to analyze the implementation of the lesson plan documents made by the subject, observations were conducted on the subjects in their teaching practice and on the character development that appeared in the students during the teaching practice. These observations were carried out by involving the principal to provide an evaluation on the teacher and the development of student character in the teacher's teaching practice. In the evaluation of the characters that appear, the school principal was assisted by a number of university students. The university students' task was only to assist in technical evaluation, namely recording the observation sheet as in Table 2 and Table 3 to assess the achievement of the characters in the PE learning carried out by the subject.

Using the instruments as in Table 2, the results of the evaluation of the subjects' teaching practices made by the principals are presented in Table 7:

Table 7. Evaluation Results by the Principals on the PE Teacher Teaching Practices

\begin{tabular}{lc}
\hline Criteria & Number of Subject \\
\hline Very Good & 2 \\
Good & 20 \\
Fair & 6 \\
Poor & 0 \\
Very Poor & 0 \\
\hline Sum & $\mathbf{2 8}$ \\
\hline
\end{tabular}


Table 7 shows that the learning practices of the majority of the teachers were good. This can be seen from the number of subjects who gained a very good score as many as two $(7.14 \%)$ subjects, and those with good scores as many as 20 $(71.42 \%)$ subjects. Six $(21.42 \%)$ subjects gained 'fair' and this drew attention and more information is needed from the principals by conducting a number of semi-structured interviews. Information was obtained that the subjects gained the score because there were several aspects in the lesson plans that were not implemented in the teaching practice. For example, in the plan, there were various learning methods or models such as cooperative learning, discussion, assignment, and reinforcement, yet there were only one in practice. However, in general, the teaching practice of the PE teachers were good.

As for evaluating the students' character development of in the learning process, the instrument as illustrated in Table 3 in measuring the achievement of the character development in PE learning was used. The results of the principal's evaluation of the achievement of student character development in the teaching practice of the PE teachers are described as in the following table:

Table 8. Evaluation Results of Student Character Achievement in the PE Teachers' Teaching Practices

\begin{tabular}{llc}
\hline \multicolumn{1}{c}{ Score } & \multicolumn{1}{c}{ Description } & Sum \\
\hline $91 \%-100 \%$ & Very Good & 0 \\
$61 \%-80 \%$ & Good & 4 \\
$41 \%-60 \%$ & Fair & 6 \\
$21 \%-40 \%$ & Poor & 18 \\
$0 \%-20 \%$ & Very Poor & \\
\hline Total & & 28 \\
\hline
\end{tabular}

From the above table, the fact that the results of the principal's evaluation of the PE teachers' teaching practice was quite problematic because it was considered still lacking in developing the students' character in the learning process. This is evidenced by the score range of $61-80 \%$ gained by four $(14.28 \%)$ subjects, $41-60 \%$ gained by a six $(21.42 \%)$ subjects, and $21-40 \%$ gained by $23(82.14 \%)$ subjects. This data led to semi-structured interviews with the research subjects. Four teachers representing each area were asked the question "Do you always evaluate the characters that grow in the learning process?" Four teachers answered, "Always" and it was followed up with the question, "How do you evaluate it?" and they answered, "By observation." Then they were asked "Do you have a guide to character assessment instruments?" All subjects answered "No." Next they were asked the question whether the results of the character evaluation are documented. Teacher 1 answered "Yes" and Teacher 2 answered "Yes, for the record only," while Teachers 3 and 4 did not document them. From the results of this interview, it can be concluded that the teachers did not have instruments in evaluating the character that developed in the learning process and the evaluation was only done as a note or as a supplement. This can impact the absence of a reflection process on the teacher in an effort to improve the quality of learning in developing student character. This data also shows a contradiction with the subject's claim in Table 4 which mostly stated that they had succeeded in developing student character. 
Nevertheless, the fact that the subjects gained a minimal score does not mean that the teachers did not develop character in the PE learning process. As a form of their commitment in developing student character in the learning process as they claimed in Table 4, there are several indicators that they had managed to grow in the learning process. The following figures map the results of the principal's evaluation on the achievement of the developed character indicator.

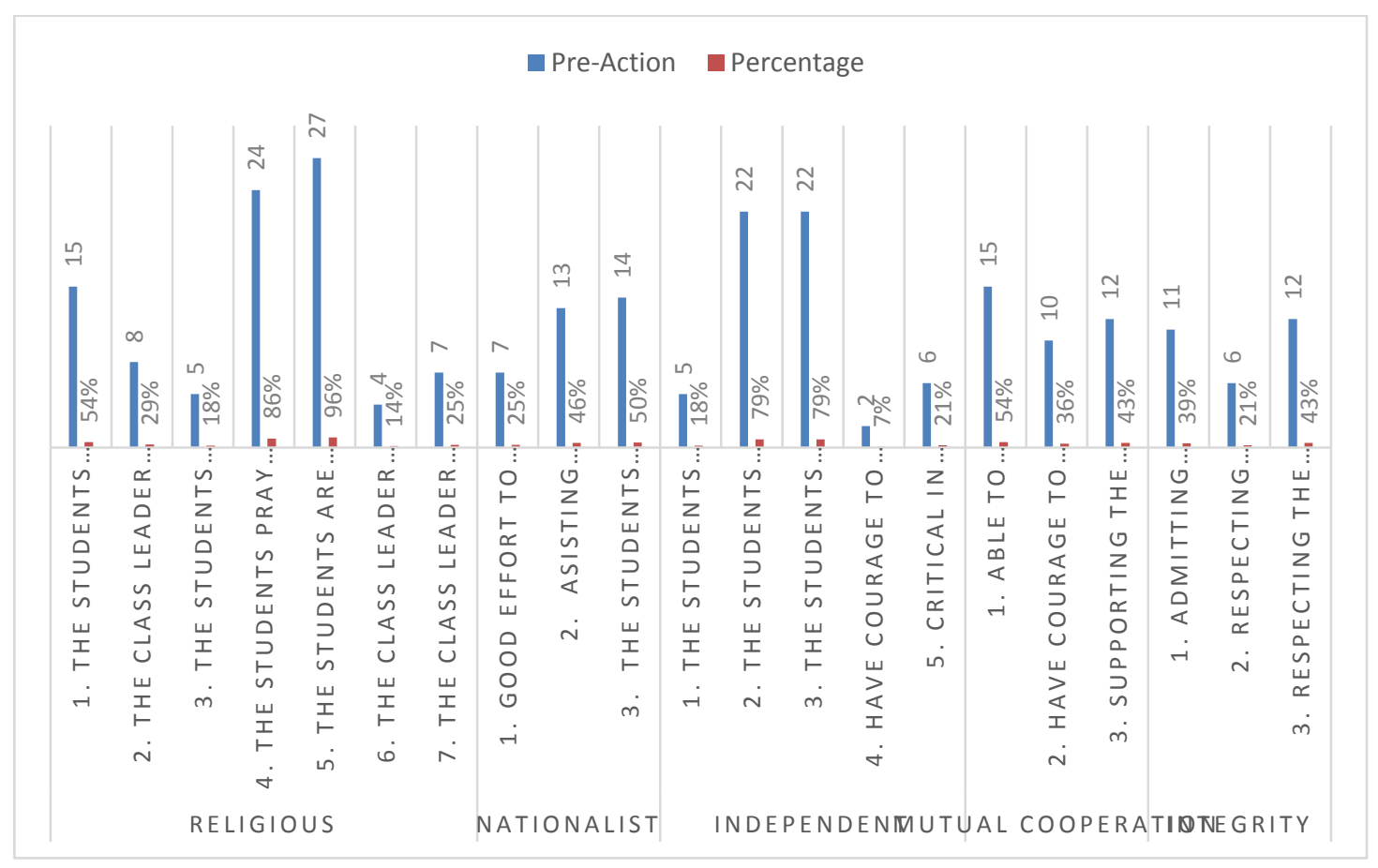

Figure 1. Achievement of Character Development in PE Learning Practices

Figure 1 above shows that in the development of religious character, only two indicators were the most successfully developed by the subject namely the fourth indicator by $24(86 \%)$ subjects and the fifth indicator by $27(96 \%)$ subjects. The other indicators -1, 2, 3, 6 and 7-were not much developed by the subjects. The first indicator was successfully developed by 15 (54\%) subjects, the second by eight $(29 \%)$ subjects, the third indicator by five $(18 \%)$ subjects, the sixth by four (14\%) subjects, and the seventh by seven (25\%) subjects.

In the nationalist character, the first indicator was successfully developed by seven $(25 \%)$ subjects, the second by $13(46 \%)$ subjects, and the third indicator by $14(50 \%)$ subjects. In the independent character, the second and third indicators are the indicators most developed by the subject. The second indicator was developed successfully by $22(79 \%)$ subjects, the third indicator by $22(79 \%)$ subjects. The first indicator was successfully developed by $5(18 \%)$ subjects, the fourth indicator by $2(7 \%)$ people, and the fifth indicator by six $(21 \%)$ subjects.

Furthermore, the character development of mutual cooperation in the first indicator was successfully developed by $11(39 \%)$ subjects, the second indicator by $10(36 \%)$ subjects, and the third indicator by $16(57 \%)$ subjects. For the character of integrity, the first indicator was successfully developed by $10(36 \%)$ 
subjects, the second indicator by $6(21 \%)$ subjects, and the third indicator by 12 $(43 \%)$ subjects.

\subsection{Pre-Action Evaluation Results}

Character development in PE learning carried out by the subject was still less than optimal thus corrective actions were needed. The corrective actions were carried out in terms of lesson planning, the material presented, the methods used, as well as the steps in developing student character in the learning process. Based on this consideration, several causes of the inoptimal character development implemented by the research subject or PE teacher in Sumedang Regency were strongly suspected, which include:

1. Poor understanding of the concept of character education.

2. Learning materials delivered lacked character development.

3. The methods used by the teachers lacked of exploring character development.

4. The teachers did not have the instrument to achieve character values in the evaluation.

\subsection{Action and Critical Evaluation on Physical Education Learning}

Based on the results of the pre-action evaluation, several corrective actions were compiled including the development of character-based teaching materials, increasing the competency of PE teachers in developing student characters in PE learning, and implementation of character education in PE learning and its evaluation. Every action implementation involves reflective, critical, and practical steps. The following describes the actions taken which are accompanied by diligent observation on subject's responses.

\subsubsection{Character-Based Learning Material Development}

Efforts were made to develop PE learning materials that had character content. Results of observations and FGDs with the principals in particular showed that the teachers had not yet had a manual or module that emphasizes the inculcation of character values. The developed module has two parts. The first part contains the basic concepts of character education and the method of internalizing character values. This section is intended to provide a deeper understanding of the concept of character education for teachers because basically teachers already have sufficient knowledge about character education and methods for developing character in PE learning. The second part contains the character-based PE learning process that emphasizes on three materials, namely baseball games, rhythmic gymnastics, and healthy living culture. The reason for the selection of the three materials is because the scope of the PE material in elementary schools includes elements of games, sports, and health. The three materials represent the three scopes of PE learning, baseball represents the elements of the game, gymnastics represents the element of sports, and the culture of healthy living represents the element of health.

Before the module was implemented, it was validated by involving 3 teams of experts from academics, practitioners, and users. The academic element consisted of one PE lecturer and one religious education lecturer. From the practitioners' element, two principals from each region and two PE teachers 
were involved. The user element consisted of supervisors from the education office. The results the assessment questionnaire for the module can be seen in Table 9 and 10 below:

Table 9 Expert Team Validation of Module 1

\begin{tabular}{|c|c|c|c|c|c|c|c|c|}
\hline & \multirow[t]{2}{*}{ Assessed Aspect } & \multicolumn{2}{|c|}{$\begin{array}{c}\text { Academician } \\
\mathrm{s}\end{array}$} & \multicolumn{4}{|c|}{ Practitioners } & \multirow{2}{*}{$\begin{array}{c}\text { User } \\
\text { U }\end{array}$} \\
\hline & & PL & RL & P1 & P2 & T1 & T2 & \\
\hline 1. & $\begin{array}{l}\text { Relevance between the title and } \\
\text { content }\end{array}$ & 4 & 4 & 4 & 4 & 4 & 4 & 4 \\
\hline 2. & Clear objectives & 4 & 4 & 4 & 4 & 4 & 4 & 4 \\
\hline 3. & Orderly writing systematic & 3 & 4 & 4 & 4 & 4 & 4 & 3 \\
\hline & $\begin{array}{l}\text { Effective and straightforward } \\
\text { language }\end{array}$ & 4 & 3 & 4 & 4 & 3 & 3 & 3 \\
\hline 5. & Sufficient material substance & 3 & 3 & 4 & 4 & 4 & 4 & 4 \\
\hline 6. & Novelty in the methods & 5 & 5 & 5 & 5 & 5 & 5 & 5 \\
\hline 7. & Sufficient literature review & 4 & 4 & 4 & 4 & 4 & 4 & 4 \\
\hline & Sufficient references & 4 & 4 & 4 & 4 & 4 & 4 & 4 \\
\hline & & 31 & 31 & 33 & 33 & 32 & 32 & 31 \\
\hline & erage & 3.87 & 3.87 & 4.12 & 4.12 & 4 & 4 & 3.875 \\
\hline
\end{tabular}

Score: 5 = Very Good, 4 = Good, 3 = Fair, 2 = Poor, 1 = Very Poor

$\mathrm{PL}=\mathrm{PE}$ Lecturer, $\mathrm{RL}=$ Religious Education Lecturer, $\mathrm{P}=$ Practitioner, $\mathrm{U}=$ User

Table 9 shows the assessment results of the expert team that Module 1 is "good" with the assessors giving an average score of 3.98. This value was obtained from the sum of scores obtained divided by the number of assessors. The largest score was obtained in the aspect of novelty in the methods.

In the methods of developing character in learning activities, the teachers need to emphasize on an aspect. A teacher is required to be able to learn all dimensions of humanity. These dimensions include spirituality, reason, lust, and physicality which are human potentials in the framework of education.

The success of teachers in delivering all dimensions is shown by the ability to recognize and understand the nature of the elements that exist in human beings. For example, reason is rational and if something is irrational then reason will reject it; lust, that always wants to be satisfied, will always encourage humans to continue to fulfill it, and so on.

After understanding the character of the human dimension, the teacher performed actions of value based on the character's dimensions with learning techniques such as habituation, understanding, strengthening, control, and practice, so that the results of the learning were embedded in characters that will later be developed in learning activities. In short, it can be described as follows: 
Table 10. The concept of Instilling Values of Character

\begin{tabular}{|c|c|c|c|c|c|}
\hline Dimension & Character & Aspect & Value Action & Learning & $\begin{array}{l}\text { Extern } \\
\text { alizati } \\
\text { on }\end{array}$ \\
\hline Spirituality & $\begin{array}{l}\text { Transcenden } \\
\text { ce }\end{array}$ & Esoteric & Spiritualizing & Enlivened & Soft \\
\hline Reason & Rational & Cognitive & $\begin{array}{l}\text { Conceptualizi } \\
\text { ng }\end{array}$ & Understood & Smart \\
\hline Feelings & Compliance & Affective & Internalizing & $\begin{array}{l}\text { Strengthen } \\
\text { ed }\end{array}$ & $\begin{array}{l}\text { Longin } \\
\mathrm{g}\end{array}$ \\
\hline Lust & $\begin{array}{l}\text { Self- } \\
\text { satisfying }\end{array}$ & Psychomotor & Dissonance & Controlled & $\begin{array}{l}\text { Obedi } \\
\text { ent }\end{array}$ \\
\hline Physique & $\begin{array}{l}\text { Ready for } \\
\text { action }\end{array}$ & Motor & Actualization & Practiced & $\begin{array}{l}\text { Tame/ } \\
\text { skilled }\end{array}$ \\
\hline
\end{tabular}

The character components in externalization were then developed and in PE learning by developing the intrinsic values of character in strengthening character education based on student development. Furthermore, the validation of Module 2 is presented in the following table:

Table 11. Expert Team Validation on Module 2

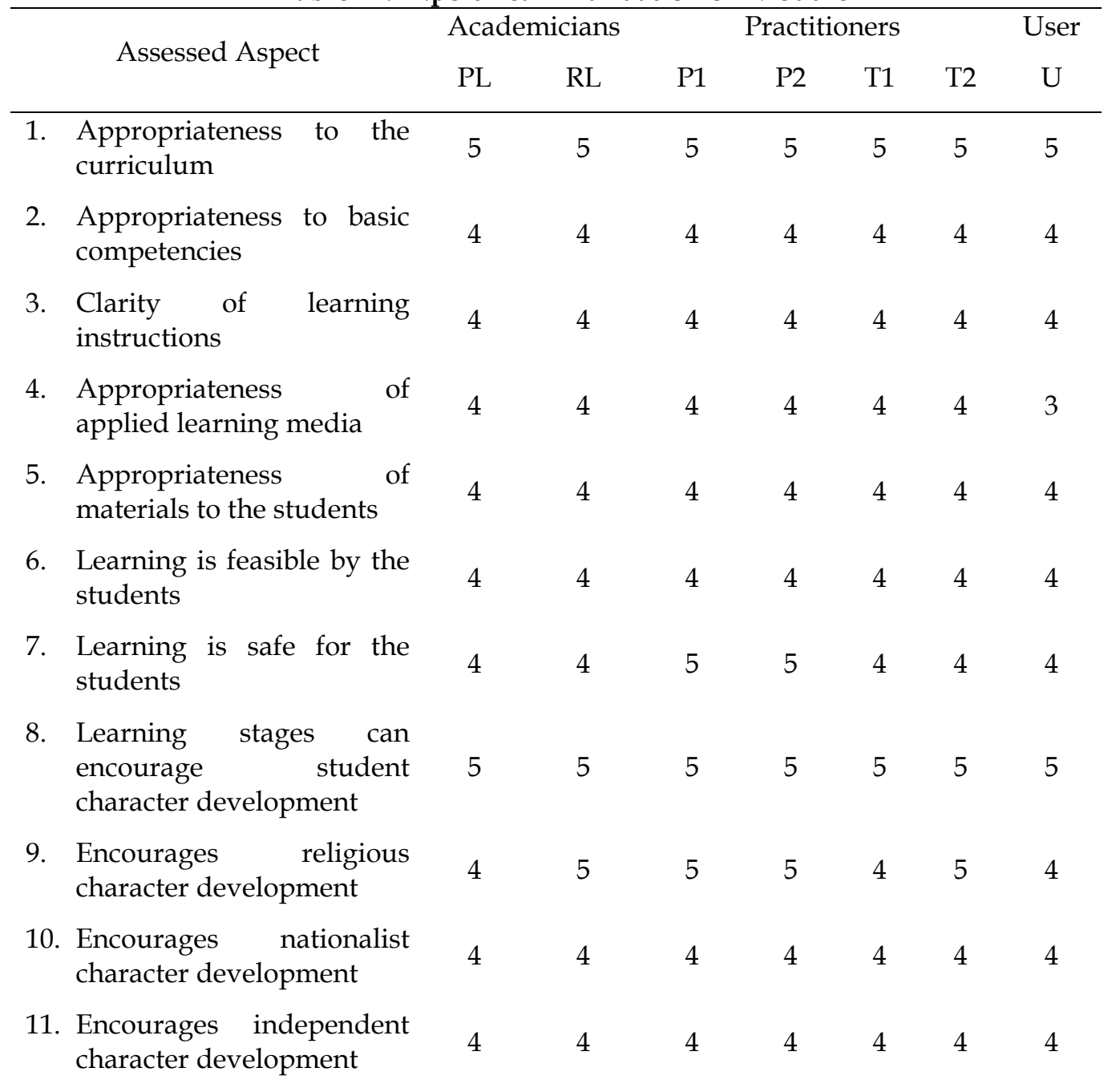




\begin{tabular}{|c|c|c|c|c|c|c|c|c|}
\hline 12. & $\begin{array}{l}\text { Encourages } \\
\text { cooperation } \\
\text { development }\end{array}$ & 4 & 4 & 4 & 4 & 5 & 5 & 4 \\
\hline 13. & $\begin{array}{l}\text { Encourages integrity } \\
\text { character development }\end{array}$ & 4 & 3 & 4 & 4 & 4 & 4 & 4 \\
\hline 14. & $\begin{array}{l}\text { Encourages student } \\
\text { interest and motivation in } \\
\text { participating }\end{array}$ & 4 & 4 & 4 & 4 & 4 & 4 & 4 \\
\hline 15. & $\begin{array}{l}\text { Encourages the student to } \\
\text { move actively }\end{array}$ & 5 & 4 & 4 & 5 & 5 & 4 & 4 \\
\hline$\overline{\mathrm{ScC}}$ & & 63 & 62 & 64 & 65 & 64 & 64 & 61 \\
\hline & erage & 4.20 & 4.13 & 4.26 & 4.33 & 4.26 & 4.26 & 4.06 \\
\hline
\end{tabular}

Score: 5 = Very Good, 4 = Good, 3 = Fair, 2 = Poor, 1 = Very Poor

\section{$\mathrm{PL}=\mathrm{PE}$ Lecturer, $\mathrm{RL}=$ Religious Education Lecturer, $\mathbf{P}=$ Practitioner, $\mathrm{U}=$ User}

Based on the above table, it can be concluded in the assessment of module 2 produces, the team gave an average score of 4.21 which is in the "good" category. This value is obtained from the average score obtained divided by the number of evaluators. The largest score obtained from all assessors is in the aspect of novelty elements in the learning stages of character development. The stages in the character-based PE learning were as follows:

\section{Stage 1. Spirituality}

The teachers always enlivened spiritual values in learning. The form of activities were such as carrying out joint prayers at the beginning and end of the activity, checking the neatness of clothes and personal hygiene, and cleanliness of the environment, as well as environmental care programs. This stage should be the spirit in all the series of learning activities.

\section{Stage 2. Planning}

In this stage, PE learning was designed and planned appropriate to the students' character development and in accordance with the applicable curriculum. The form of activity in this stage was that the teacher compiled lesson plan documents.

\section{Stage 3. Organization}

This stage contains organizing materials based on didactic principles from easy to complex in learning activities. The scope of the intended learning activities was at the opening, main, and closing activities with the principle of $5 \mathrm{~W} 1 \mathrm{H}$ (What, Why, Who, Where, When, and How).

\section{Stage 4. Reflection and Repetition}

The implementation of learning was always accompanied by reflection in an effort to improve the quality of learning by paying attention to student responses. Furthermore, repetition is the process of reminding students before discussing new materials. 


\section{Stage 5. Togetherness}

Enforcement of disciplinary rules was an effort to control the class and create a climate of togetherness and to educate students to always be ready to learn with anyone in the research group.

\section{Stage 6. Internalization}

The teachers included instilling values in learning through stories or short films and then the teachers gave meaning to the stories or films. The internalization of values could be done by growing awareness of environmental phenomena and giving meaning to the phenomena.

\section{Stage 7. Value}

The character values that grow in the learning process were observed and the efforts to familiarize and maintain the growth of those values were done. The observation process was always accompanied by reflection activities as an effort to evaluate and to plan improvements.

\section{Stage 8. Evaluation}

An evaluation was conducted on the learning sequence to measure the extent of learning achievement. The evaluation was carried out in various ways such as summative, formative, observation, assessment rubric, and so on.

\subsubsection{Lesson Plan Document Development Process}

After validating Modules 1 and 2, a seminar and workshop on character education was conducted. The output of this activity was the production of PE lesson plan development document based on character strengthening. The development was manifested in the selection of the characters that would be developed in the document, as well as the method of character development and the stages in learning. The documents were then evaluated by the principals as in Table 2, in which the documents were compared with the results from the pre-action evaluation. The evaluation results are illustrated as follows:

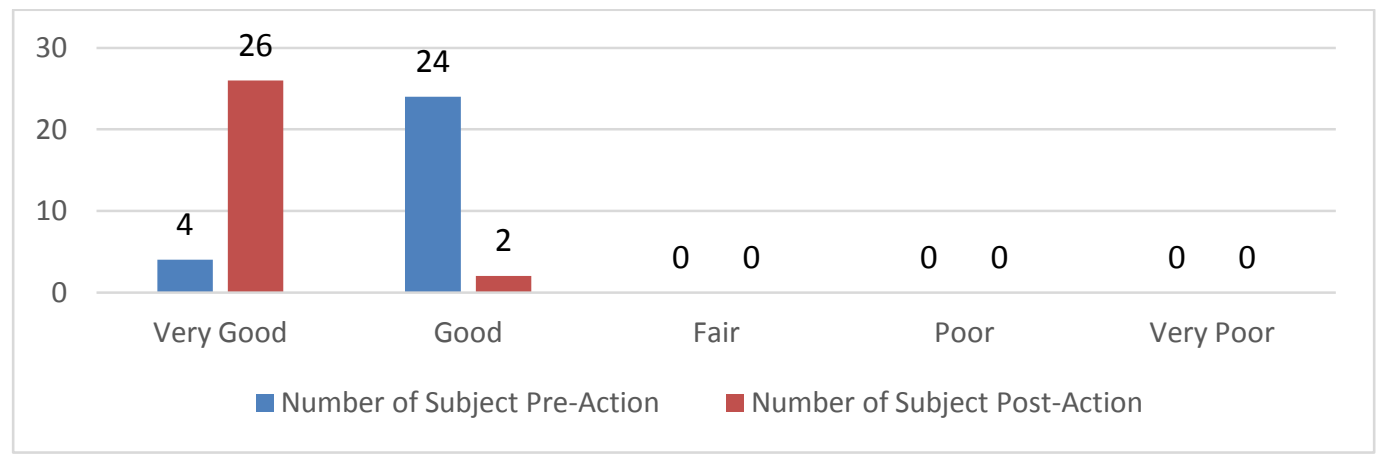

Figure 2. Evaluation Results of Lesson Plan Documents

Figure 2 shows that there are changes in the principals' evaluation of the lesson plan documents made by the research subjects. In the pre-action, a very good score were given to four $(14.28 \%)$ subjects, while in the post-action a very good score were given to $26(92.8 \%)$ subjects. This means that there was an improvement in the subject's quality in compiling lesson documents as much as $78.6 \%$. 


\subsubsection{Character-Based Physical Education Learning Practices}

After compiling the document, the following is the principal's evaluation of the implementation of the learning activities carried out by the subject. The evaluation was carried out using IPKG 2. By comparing the results with preaction, the results of the evaluation in learning practices are presented in the following figure:

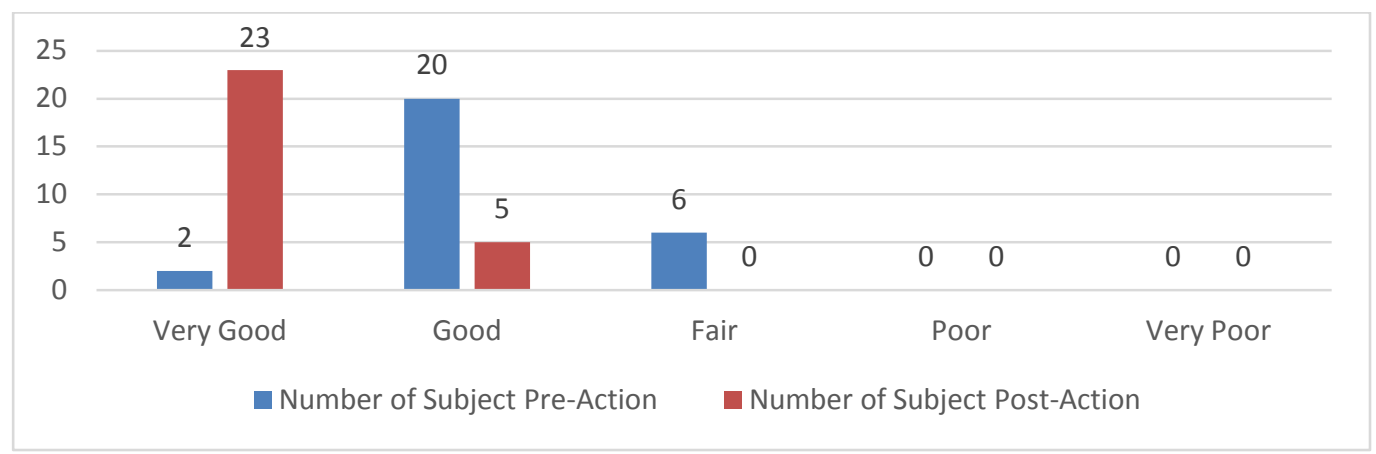

Figure 3. Evaluation Results of Learning Practices

Seen in Figure 3 above, there are improvements in the quality of learning implementation. In the pre-action, two $(7.14 \%)$ subjects gained very good score, while in the post-action $23(82.14 \%)$ subjects gained the score. In the pre-action, the six $(21.42 \%)$ subjects gained fair score, while in the post-action no subjects obtained the score. It can be interpreted that a number of teachers improved a level from good to very good, as many as $20(71.42 \%)$ subjects. There were also one subject $(3.57 \%)$ that improved two levels, namely from fair to very good . Thus, in the learning practice, 21 (75\%) subjects made improvements.

\subsubsection{Post-Action Character-Based Physical Education Learning Evaluation}

By using the same techniques and instruments in the pre-action, character-based PE learning carried out by the subject was evaluated, and the pre-action and post-action results were compared. The comparison results of character development in the teaching practice of the research subjects are shown in Figure 5. 


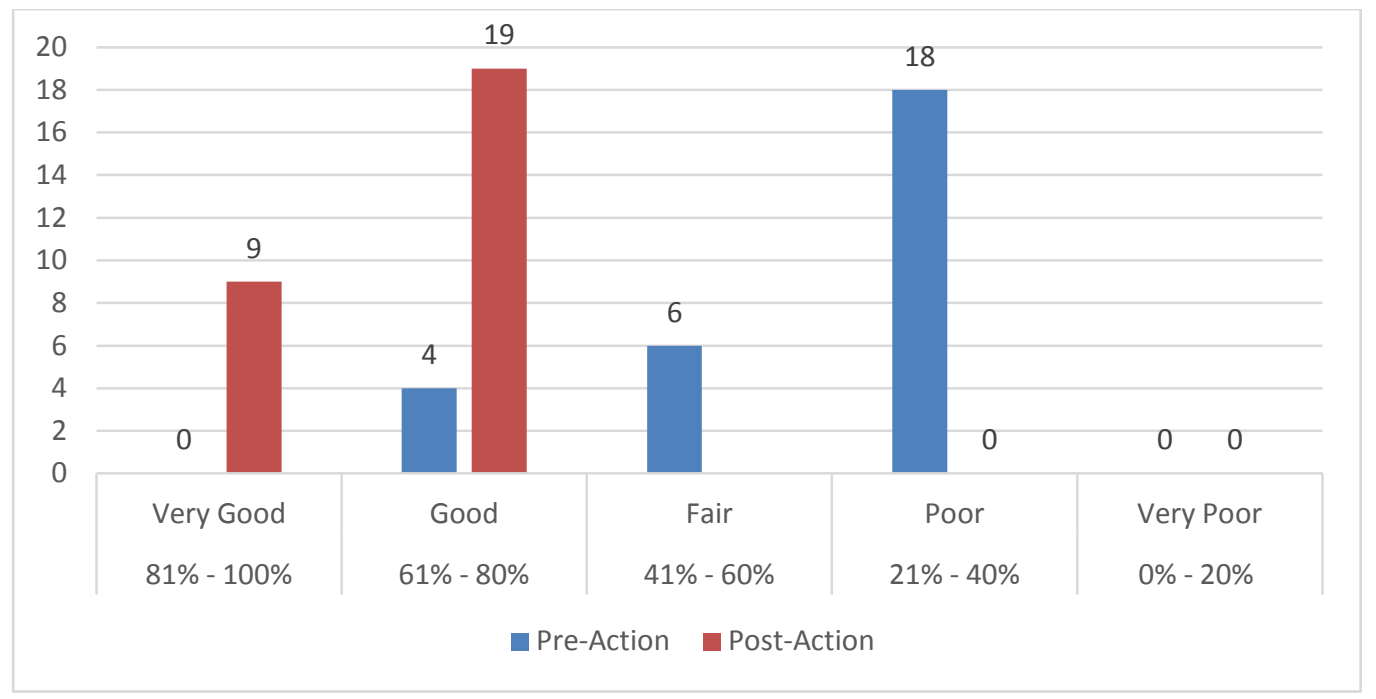

Figure 4. Evaluation Results of Character Achievement in PE Learning

Figure 4 shows the results of the principals' evaluation of the development of student character in the post-action teaching practice of the PE teachers. In the post-action, no teacher gained a score in the range $21 \%-40 \%$ (Poor) and the range $41 \%-60 \%$ (Fair). In the post-action, the score range of $61 \%-80 \%$ was obtained by $19(67.85 \%)$ subjects. This means that there has been an increase from pre-action of 15 (53.57\%) subjects. As for the score range of $81 \%-100 \%$ as many as $9(32.14 \%)$ subjects obtained it, while in the pre-action no teacher gained this score. Thus, the taken actions could improve teacher skills in developing student characters to $24(85.71 \%)$ subjects.

\subsection{Evaluation Results of Post-Action}

The increase in the scores of PE learning practices undertaken by the research subjects shows that the stages of action given to the subjects succeeded in improving teacher competencies in developing five main characters in $\mathrm{PE}$ learning. The results of the increase in the number of teachers who were able to develop the indicators are presented in Figure 6. 


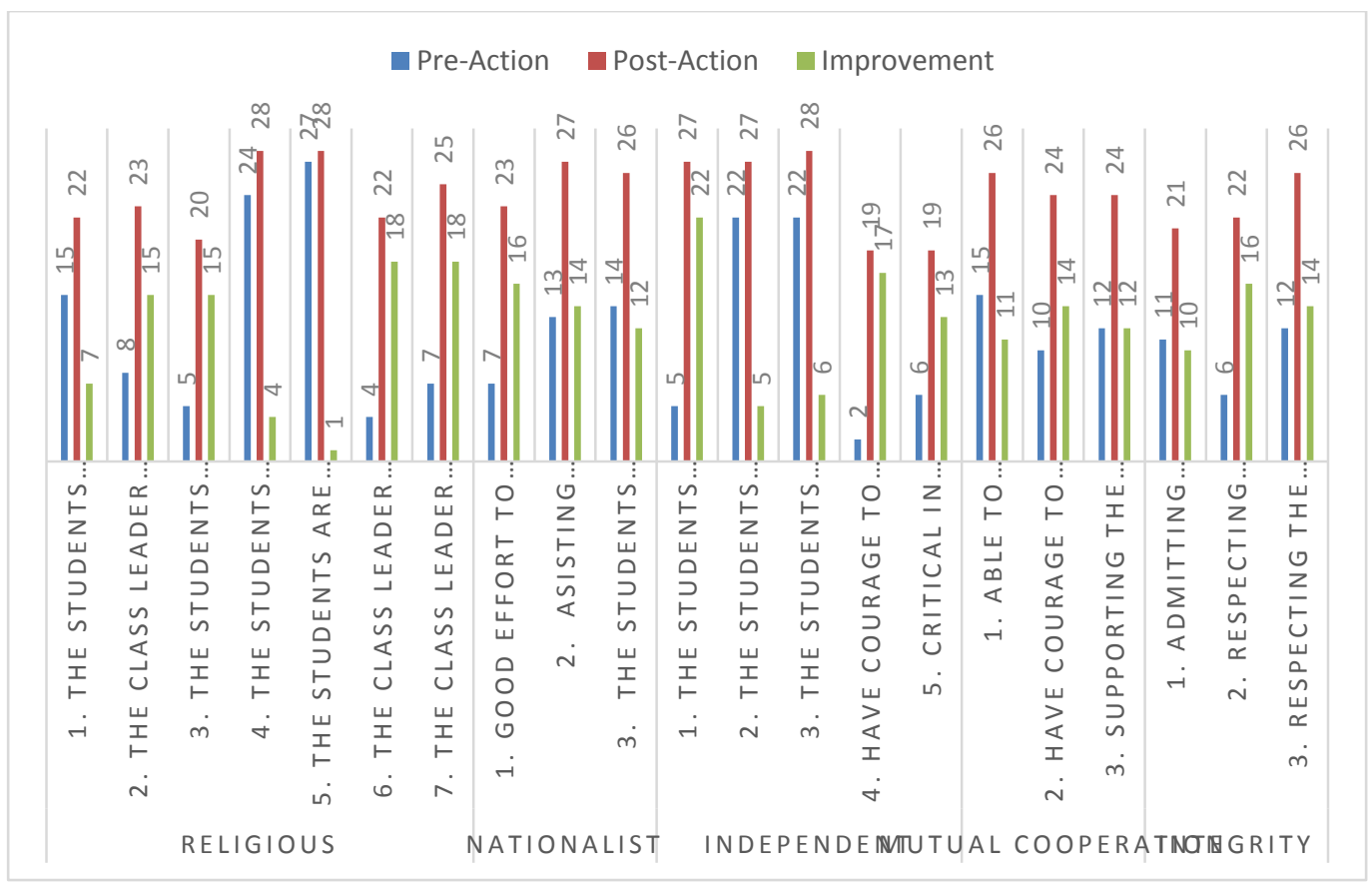

Figure 5. Increase in Number of Subjects Being Able to Improve Character Indicator

Figure 5 shows that there is an increase in the number of research subjects in developing the five main characters in PE learning activities. In religious characters there are subjects who can develop characters in all indicators except the fifth indicator in a fixed amount. The first indicator there is an increase by 7 (25\%) subjects, the second indicator by $15(53.57 \%)$ subjects, the third indicator by $15(53.57 \%)$ subjects, the fourth indicator by $4(14.28 \%)$ subjects, the sixth indicator by 18 (64\%) subjects, and the seventh indicator by $22(78.57 \%)$ subjects.

In the nationalist character there is an increase in the number of subjects who are able to develop all the indicators namely in the first indicator by $16(57.14 \%)$ subjects, the second indicator by $14(50 \%)$ subjects, and the third indicator by 12 $(42.85 \%)$ subjects.

In the independent character there is an increase in the number of subjects who are able to develop the indicators, namely in the first indicator by $22(78.57 \%)$ subjects, the second indicator by $5(17.85 \%)$ subject, the third indicator by 6 $(21.42 \%)$ subjects, the fourth indicator by $15(53.57 \%)$ subjects, and the fifth indicator by $13(46.42 \%)$ subjects.

In mutual cooperation character there is an increase in the number of subjects who are able to develop the indicators. In the first indicator there was an increase by 11 (39.28) subjects, the second indicator by 14 (50\%) subjects, and the third indicator by $12(42.85 \%)$ subjects.

In the integrity character there is an increase in the number of subjects who are able to develop the indicators, namely in the first indicator by 10 (35.71) subjects, the second indicator by $16(57.14 \%)$ subjects, and the third indicator by $14(50 \%)$ subjects. 


\section{Discussion}

The aforementioned research results provide new evidence that along with increasing teacher understanding and skills in this case increasing pedagogic competence, physical activity in PE learning is able to develop students' character, especially in the five main characters as national character, which is the government's program to strengthen character education in schools. Abduljabar (2014) states that PE can be used as a mediation process for the formation of positive student character by always focusing on the value of the task of learning motion that is designed in the setting of intellectual, emotional, and social interventions. Learning approaches that need to be used in efforts to shape positive character are value education, reflective teaching, contextual teaching, as well as learning instruction and patterns of mentoring and nurturing in a positive-natural atmosphere. PE needs to be redirected to its nature as an education through physical activities (back to basics).

Still according to Abduljabar (2014), the process of character instillation in PE learning oriented to the value of physical activity needs to be didactic. Moreover, PE teachers need to shift their paradigm in teaching PE from head start to heart start as revealed by Ratna $(2009, p$. 37) that one of the causes of character loss in the world of education is because education paradigm has tended to emphasize more on head start (IQ intelligence) instead of heart start (emotional intelligence). She argued that the headstart paradigm emphasizes that children "must be able to..." so that there is a tendency for children to learn too early (early childhood training). Cases such as antisocial personality disorder, learning disability, and others are resulted from the headstart education paradigm.

Therefore, Maksum's (2017 p.1) statement that the character in the world of sports or PE is only a claim without scientific evidence, yet it is not entirely true and not entirely wrong. This is very closely related to the professionalism of a teacher. The failure of PE to build student character is closely related to the quality of a teacher because quality PE is born from qualified teachers (Maksum, 2010). The teacher lacks quality because he or she does not show professionalism and tend to avoid difficulties and want to have instant results (Supriyadi \& Julia, 2019). Whereas teacher professional learning is a complex process, which requires cognitive and emotional involvement of teachers individually and collectively, the capacity and willingness to examine where each one stands in terms of convictions and beliefs and the perusal and enactment of appropriate alternatives for improvement or change (Avalos, 2011).

When PE learning needs to develop positive character of students or emphasize character education, the focus of teaching needs to be on the context of student learning for the students' social development and put aside the technical skills of certain sports branch skills. This is called integrated PE (Suherman, 2018). Therefore, PE teachers are required to be active, innovative, and creative in teaching so that children have strong willingness or comfort in learning. PE teachers also need to change learning styles that are conventional in nature which tend to be monotonous, unattractive, and uninteresting. Moreover, PE teachers also need to develop learning models that support the success of the teaching process. 
Teachers need to constantly reflect on themselves and continue to strive to improve the quality of learning, and understand learning styles and teaching styles that can create a change in the learning process. This means that teachers must be fully aware that the learning steps in the learning process carried out so far have not been able to provide satisfactory results. Therefore, it is necessary to develop innovative and futuristic models, because in addition to the learning model it is closely related to the style of learning and teaching. The learning model can also be interpreted as an approach to deal with changes in student behavior in an adaptive or generative manner (Hanafiah \& Suhana, 2009). In addition, learning models can also help students in achieving learning goals (Joyce, B. Weils, M. Calhoun, 2003).

The teachers' ability to develop models suggests that teachers must also have literacy skills (Supriyadi \& Julia, 2019), by exploring research that can improve their abilities such as how to research teacher learning and propose or discuss models of professional teacher learning (Castle, 2006; James \& McCormick, 2009; Nisbet \& Shucksmith, 2017; Novak \& Gowin, 1984; Olson \& Craig, 2001). This is done in an effort to improve how teachers learn and change by developing theory or applying theory to the discussion of teacher change (Clarke \& Hollingsworth, 2002; Korthagen, 2010; Korthagen, 2004; Penlington, 2008). Therefore, as a result of this research implies, teachers need to practice the action research approach in an effort to improve and improve the quality of learning.

\section{Conclusion}

This research has shown facts that developing national character of elementary school students through PE learning requires eight fundamental steps in the learning process. We name these eight steps into a learning model named SPORTIVE. It is an acronym of $S=$ Spiritual, $\mathrm{P}=$ Planning $\mathrm{O}=$ Organization, $\mathrm{R}=$ Reflection and Repetition, $\mathrm{T}=$ Togetherness, $\mathrm{I}=$ Internalization, $\mathrm{V}=$ Value, and $\mathrm{E}$ $=$ Evaluation.

The eight steps organized in this acronym is an effort to optimize the harmonization of students' potential development in their heart (ethics), thought (literacy), feeling (aesthetics), and body (kinesthetic). Thus, this SPORTIVE learning method can be an alternative to develop five national characters (religious, nationalist, independent, mutual cooperation, and integrity) of elementary school students through PE learning. However, this model is open to be redeveloped.

The process of PE learning integrated with character education result in a conducive and effective learning climate since the learning is students-centred and helps achieving learning objectives. In addition, strengthening character education through PE is fundamental and is strategic to develop national identity in facing globalization challenges. This research implies that infusing character education in the learning process should not only be done in PE learning, but also in other subjects. This is believed to be significant since the success of learning in elementary school is determined by several other factors in addition to PE. Therefore, the limitations of this research are on the subjects and 
the participants. This research focuses only on the PE learning in elementary schools in terms of teachers' pedagogical understanding and skills.

Considering the above notions, we proposed the following recommendations to be followed up by academicians, and specifically by practitioners of sport education, such as sport teacher, coach, and researchers of sport: as follows:

- Embedding literacy skills development in improving teachers' pedagogical competence, hence they have better understanding of teaching methods and models of character learning to be developed in their classroom.

- Implementing SPORTIVE teaching method as a guide for sports practitioners in developing character, not only in elementary school level, but also in secondary and tertiary levels of education. Hence, the expression "sports build character" is not merely a slogan but is also manifested in reality.

- Conducting action research to improve teachers' learning performance

- Exemplifying this research in other school subjects and to different participants, but still focuses on strengthening national character education.

\section{Acknowledgement}

The researchers extend their gratitude to the Institute for Research and Community Service of the Indonesia University of Education that has facilitated the implementation of this research, and to the resource persons who have been willing to take the time to provide information and views.

\section{References}

Abduljabar, B. (2014). Memperkokoh Pendidikan Karakter melalui Mediasi Aktivitas Jasmani Berbasis Nilai [Strengthening Character Education through the Mediation of Value-based Physical Acticivities]. Jurnal Pendidikan Karakter, 4(1), 97-107.

Allen, I. E., \& Seaman, C. A. (2007). Likert scales and data analyses. Quality Progress, 40(7), 64-65.

Arifin, R., \& Warni, H. (2017). Character Building Values in Sports Development. Character Building Values in Sports Development, 1(2). doi:10.5220/0007058602310234

Avalos, B. (2011). Teacher professional development in teaching and teacher education over ten years. Teaching and Teacher Education, 27(1), 10-20. doi:10.1016/j.tate.2010.08.007

Bailey, R. (2006). Physical education and sport in schools: A review of benefits and outcomes. Journal of School Health, 76(8), 397-401. doi:10.1111/j.17461561.2006.00132.x

BNSP. (2004). Standar Isi[standard content]. Jakarta: Depdiknas

Bozkus, K., \& Bayrak, C. (2019). The Application of Dynamic Teacher Professional Development Approach Through Experimental Action Research. International Electronic Journal of Elementary Education, 11(4), 335-352. doi:10.26822/iejee.2019450792

Brigham, T. J. (2014). Taking advantage of Google's Web-based applications and services. Medical Reference Services Quarterly, 33(2), 202-210. doi:10.1080/02763869.2014.897521 
Bruce, C. D., Flynn, T., \& Stagg-Peterson, S. (2011). Examining what we mean by collaboration in collaborative action research: A cross-case analysis. Educational Action Research, 19(4), 433-452. doi:10.1080/09650792.2011.625667

Castle, K. (2006). Autonomy through pedagogical research. Teaching and Teacher Education, 22(8), 1094-1103. doi:10.1016/j.tate.2006.07.001

Chiu, C.-H., Cheng, H.-W., \& Wu, C.-Y. (2016). Applying questioning or reading strategy to review technology enhanced coedited notes of elementary school students. The Journal of Educational Research, 109(2), 111-121. doi:10.1080/00220671.2014.924471

Clarke, D., \& Hollingsworth, H. (2002). Elaborating a model of teacher professional growth. Teaching and Teacher Education, 18(8), 947-967. doi:10.1016/s0742051x(02)00053-7

Creswell, J. W. (2002). Educational research: Planning, conducting, and evaluating quantitative. Prentice Hall Upper Saddle River, NJ.

Darwis, R. S. (2016). Membangun Desain dan Model Action Research dalam Studi dan Aksi Pemberdayaan Masyarakat [Creating Action Research Design and Model in Studies and Actions of Society Empowerment]. KOMUNIKA, 10(1), 142-153. doi:10.24090/komunika.v10i1.869

Docheff, D. (1997). Character in Sport and Physical Education. Journal of Physical Education, Recreation \& Dance, 68(9), 34. doi: 10.1080/07303084.1997.10605026

Edwards-Groves, C., \& Kemmis, S. (2016). Pedagogy, Education and Praxis: understanding new forms of intersubjectivity through action research and practice theory. Educational Action Research, 24(1), 77-96. doi:10.1080/09650792.2015.1076730

Ferguson-Patrick, K. (2007). Writers develop skills through collaboration: an action research approach. Educational Action Research, 15(2), 159-180. doi:10.1080/09650790701314585

Gough, R. W. (1998). A practical strategy for emphasizing character development in sport and physical education. Journal of Physical Education, Recreation \& Dance, 69(2), 18-20. doi:10.1080/07303084.1998.10605063

Greenwood, D. J., \& Levin, M. (2006). Introduction to action research: Social research for social change. SAGE publications.

Hanafiah, N., \& Suhana, C. (2009). Konsep strategi pembelajaran [Concepts of Learning Strategies]. Bandung: Refika Aditama.

Indonesia, P. R. (2003). Undang-undang Republik Indonesia nomor 20 tahun 2003 tentang sistem pendidikan nasional [Law of the Republic of Indonesia No. 20 of 2003 on National Education System]. Jakarta: Pemerintah Republik Indonesia.

J.Julia and Tedi Supriyadi. (2017). The Implementation of Character Education at Senior High School. In Global Conference on Teaching, Assessment, and Learning in Education (GC-TALE 2017) (pp. 1-6). Bali. doi:10.1051/shsconf/20184200085

Jaipal, K., \& Figg, C. (2011). Collaborative action research approaches promoting professional development for elementary school teachers. Educational Action Research, 19(1), 59-72. doi:10.1080/09650792.2011.547688

James, M., \& McCormick, R. (2009). Teachers learning how to learn. Teaching and Teacher Education, 25(7), 973-982. doi:10.1016/j.tate.2009.02.023

Jay B Nash. (1933). The Role of Physical Education in Character Education. The Journal of Health and Physical Education, 4(3), 28-69. doi: 10.1080/23267240.1933.10625629

Jefferson, R. N. (2014). Action Research: Theory and Applications. New Review of Academic Librarianship, 20(2), 91-116. doi: 10.1080/13614533.2014.921536

Joyce, B. Weils, M. Calhoun, E. (2003). Models of Teaching. Pearson Education, Inc

Kemendikbud, R. I. (2017). Konsep dan Pedoman Penguatan Pendidikan Karakter [Concepts and Guidelines for Strengthening Character Education]. Jakarta. 
Peraturan Presiden (Perpres) Nomor, 87.

Kemmis, S., \& McTaggart, R. (2005). Participatory action research: Communicative action and the public sphere. Sage Publications Ltd.

Kemmis, S., McTaggart, R., \& Nixon, R. (2013). The action research planner: Doing critical participatory action research. Springer Science \& Business Media.

Koç, Y., \& Esentürk, O. K. (2018). Opinions of Physical Education Teachers on the Concept of Sportsmanship. Journal of Education and Learning, 7(1), 71-79. doi:10.5539/jel.v7n1p71

Korthagen, F. A. J. (2010). Situated learning theory and the pedagogy of teacher education: Towards an integrative view of teacher behavior and teacher learning. Teaching and Teacher Education, 26(1), 98-106. doi:10.1016/j.tate.2009.05.001

Korthagen, F. A. J. (2004). In search of the essence of a good teacher: Towards a more holistic approach in teacher education. Teaching and Teacher Education, 20(1), 77-97. doi:10.1016/j.tate.2003.10.002.

Leeman, Y., van Koeven, E., \& Schaafsma, F. (2018). Inter-professional collaboration in action research. Educational Action Research, 26(1), 9-24. doi:10.1080/09650792.2017.1301827

Lin, Y.-T., Chang, C.-H., Hou, H.-T., \& Wu, K.-C. (2016). Exploring the effects of employing Google Docs in collaborative concept mapping on achievement, concept representation, and attitudes. Interactive Learning Environments, 24(7), 1552-1573. doi:10.1080/10494820.2015.1041398

Maksum, A. (2005). Olahraga membentuk karakter: Fakta atau mitos [Sport forms character: Facts or myths]. Jurnal Ordik, 3(1), 23-30.

Maksum, A. (2010). Kualitas guru Pendidikan Jasmani di sekolah: Antara harapan dan kenyataan [The Quality of Sport Education Teacher at Schools: Between Expectation and Reality]. In Makalah dipresentasikan dalam forum penelitian Balitbang Depdiknas.

Maksum, Ali.. (2017). Riset Karakter dalam Pendidikan Jasmani [Character Research in Physical Education]. In "Implementasi nilai-nilai luhur olahraga dalam pembentukan karakter melalui Pendidikan jasmani [The Implementation of Noble Values of Sport in Forming Character through Physical Education]. Karawang: Universitas Singaperbangsa Karawang. Retrieved from https://www.researchgate.net/publication/321185180

Maraj, J. A. (1965). Physical Education and Character. Educational Review, 17(2), 103-113. doi: 10.1080/0013191650170202

McCloy, C. H. (1930). Character Building through Physical Education. Research Quarterly. American Physical Education Association, 1(3), 41-61. doi: 10.1080/23267402.1930.10625788

McTaggart, R. (1994). Participatory action research: Issues in theory and practice. Educational Action Research, 2(3), 313-337. doi:10.1080/0965079940020302

McTaggart, R. (1996). Issues for participatory action researchers. New Directions in Action Research, 243-256. doi:10.4324/9780203392935_chapter_13

Messiou, K. (2019). Collaborative action research: Facilitating inclusion in schools. Educational Action Research, 27(2), 1-13. doi:10.1080/09650792.2018.1436081

Niemi, R. (2018). Five approaches to pedagogical action research. Educational Action Research, 0(0), 1-16. doi:10.1080/09650792.2018.1528876

Nisbet, J., \& Shucksmith, J. (2017). Learning strategies.: Routledge

Novak, J. D., \& Gowin, D. B. (1984). Learning how to learn. New York: Cambridge University Press.

Oktavec, F. L. (1934). Physical Education as a Character Builder. The Journal of Health and 
Physical Education, 5(6), 12-43. doi:10.1080/23267240.1934.10620751

Olson, M. R., \& Craig, C. J. (2001). Opportunities and challenges in the development of teachers' knowledge: The development of narrative authority through knowledge communities. Teaching and Teacher Education, 17(6), 667-684. doi:10.1016/s0742051x(01)00023-3

Penlington, C. (2008). Dialogue as a catalyst for teacher change: A conceptual analysis. Teaching and Teacher Education, 24(5), 1304-1316. doi:10.1016/j.tate.2007.06.004

Qoriah, A. (2013). Guru Penjasorkes Perlu Mengerti Agama: Integrasi Pendidikan Agama Islam dalam Pendidikan Jasmani, Olahraga, dan Kesehatan [Teacher of Physical Education. Sport, and Health Needs to Understand Religion: Integratiob of Islam Education in Physical Education, Sport, and Health]. In Seminar Nasional Olahraga Penjasorkes dalam Kurikulum 2013 (pp. 144-157). Yogyakarta: Universitas Negeri Yogyakarta.

Rahayu, J. S. (2013). Kontribusi Pendidikan Jasmani dalam Membentuk Karakter Peserta Didik [Contribution of physical education in shaping the character of students]. Jurnal Pendidikan Jasmani Indonesia 9(2). 134-140

Ratna, M. (2009). Pendidikan Karakter (Character Education). Jakarta: Indonesia Heritage Foundation.

Romance, T. J. (1988). Promoting Character Development in Physical Education. Strategies, 1(5), 16-17. doi: 10.1080/08924562.1988.10591625

Somekh, B. (2010). The Collaborative Action Research Network: 30 years of agency in developing educational action research. Educational Action Research, 18(1), 103-121. doi:10.1080/09650790903484566

Suherman, A. (2018). The Implementation of Character Education Values in Integrated Physical Education Subject in Elementary School. In SHS Web of Conferences (Vol. 42, p. 45). doi:10.1051/shsconf/20184200045

Sukadiyanto, S. (2008). Peranan Matakuliah Pendidikan Jasmani di Perguruan Tinggi [Role of Physical Education Course in University]. Cakrawala Pendidikan, 3(3) 304318

Supriyadi, T. (2016). Model Pembelajaran Internalisasi Iman dan Taqwa dalam Pembelajaran PAI untuk Usia Sekolah Dasar [Learning Model of Faith and Taqwa Internalization in Islamic Education for Primary School]. Mimbar Sekolah Dasar, 3(2), 191-208.

Supriyadi, T., \& Julia, J. (2019). The Problem of Students in Reading the Quran: A Reflective-Critical Treatment through Action Research. International Journal of Instruction, 12(1). doi:10.29333/iji.2019.12121a

Travis, L. (2010). One of many free survey tools: Google docs. Journal of Electronic Resources in Medical Libraries, 7(2), 105-114. doi:10.1080/15424065.2010.482902

Widhiarso, W. (2011). Skalo program analisis skala Guttman [SKALO Program of Guttman Scale Analysis]. Yogyakarta, Indonesia: Universitas Gajah Mada.

Wuest, Deborah A and Bucher, C. A. (2003). Foundations of Physical Education, Exercise Science and Sport. McGraw-Hill Education.

Zech, L. K., Gause-Vega, C. L., Bray, M. H., Secules, T., \& Goldman, S. R. (2000). ContentBased Collaborative Inquiry: A Professional Development Model for Sustaining Educational Reform. Educational Psychologist, 35(3), 207-217. doi:10.1207/S15326985EP3503_6

Zuber-Skerritt, O. (2015). Participatory action learning and action research (PALAR) for community engagement: A theoretical framework. Educational Research for Social Change, 4(1), 5-25. 